\title{
PHYTOCHEMISTRY AND FUNGITOXIC POTENTIAL OF EXTRACT AND FRACTIONS OF Pouteria ramiflora ON Fusarium solani f. sp. phaseoli
}

\author{
FITOQUÍMICA E POTENCIAL FUNGITÓXICO DE EXTRATO E FRAÇÕES DE \\ Pouteria ramiflora SOBRE Fusarium solani f. sp. phaseoli
}

\author{
Rosemary MATIAS $^{1}$; Elvia Silvia RIZZI' ${ }^{1}$; Ademir Kleber Morbeck de OLIVEIRA ${ }^{1}$; \\ Kelly Cristina Lacerda PEREIRA ${ }^{1}$; José Antônio Maior BONO ${ }^{2}$; Bianca Orbes CORREIA ${ }^{2}$ \\ 1. Postgraduate Program in Environment and Regional Development, University Anhanguera-Uniderp, Campo Grande, MS, Brazil; 2. \\ Postgraduate Program in Agro-industrial Production and Management, University Anhanguera-Uniderp, Campo Grande, MS, Brazil. \\ akmorbeckoliveira@gmail.com
}

\begin{abstract}
Among the fungus that attack the common bean crop there is Fusarium solani f.sp. phaseoli (Fsp), causing major losses. Taking into account its importance, the objective of this work was to determine the secondary metabolites class and the potential fungicide of the Pouteria ramiflora leaves on Fsp. The ethanol extract was dissolved in methanol/water and partitioned successively with hexane, dichloromethane, chloroform, ethyl acetate and butanol, subjected to the chemical profile. The solutions were prepared in concentrations of $800,1200,1600,2000$ and $2400 \mu \mathrm{g} / \mathrm{mL}$ and poured into Petri dishes; then, $0.5 \mathrm{~cm}$ disc of diameter with spores and mycelia of $F s p$ was deposited. These dishes were incubated in temperature of $25 \pm 2{ }^{\circ} \mathrm{C}$ and the evaluations, performed by measuring the colonies diameter (five replications) until reaching the dishes border (three days) with a completely randomized experimental design. Through the Mycelial Index Growth Speed (MIGS) data, analysis of variance was performed and when significant, applied the regression analysis. The results indicated that all fractions and the extract have the phenolic compounds and/or derivatives as one of the major constituents except the hydroethanolic fraction. The extract and its fractions decreased the Fsp MIGS, in the same proportion in which concentrations were increased; the greatest reduction occurred in the butanol fraction at the concentration of $2400 \mu \mathrm{g} / \mathrm{mL}$, with growth close to zero, indicating its potential use for the $F s p$ control, probably due to the presence of anthraquinones.
\end{abstract}

KEYWORDS: Commons beans. Pathogenic fungi. Soilborne fungi. Flavonoids. Anthraquinones.

\section{INTRODUCTION}

Diseases caused by soil fungi form a complex etiology, being one of the responsible for the largest productivity losses in the cultivation areas in Brazil; among these fungi is Fusarium solani (Mart.) Sacc. f. sp. phaseoli (Burkh.) T. Aoki and O'Donnell (LESLIE; SUMMERELL, 2006). It causes the root rot and stem lesions, with secondary symptoms of yellowing, size reduction, wilting and drought in bean plants, occurring practically in all the producing regions in Brazil, in addition to infect other cultures of economic interest, such as the soy (GARCIA et al., 2014).

The root rots can kill the plant before the infructescences formation, causing a reduction of up to $100 \%$ in grain yield; the disease can be distributed in the crop isolatedly, in small groups, shrubs or, stretches due to the inoculum distribution (CASA et al., 2011). According to Reis et al. (2004), root rot, in general, are considered difficult diseases to control, due to the short duration crops rotations; considering the damages that they cause,

have received little attention by researchers.
The use of pesticides for the control of this disease has led to other problems, such as the environmental contamination. Aiming at reducing such losses, alternatives have been researched for the plant pathogens control; one of them is the biological activity exploration of secondary metabolites present in crude plants extracts and essential oils from medicinal plants of the native flora of the Cerrado biome, of great diversity and bioactive properties to be efficient in controlling the growth of a wide variety of microorganisms (DI PIERO et al., 2010).

Among the different genera that exist in that biome, one of the most disseminated is Pouteria (Sapotaceae) with great use in popular medicine. Among the genus species, Pouteria ramiflora (Mart.) Radlk., arboreal habit, has proved its biological activity. Among the studies already carried out, Oliveira et al. (2017), researching the phytochemicals action present in the leaves, evidenced the presence of anthraquinones, phenolic compounds, coumarins, flavonoids and triterpenes, e. g. with the partition of the ethanolic extract and 
its fractions by decreasing the rate of Lasiodiplodia theobromae mycelial growth.

Given the above, this study aimed to determine the secondary metabolites class from $P$. ramiflora leaves and its use through fractions and extract, in different concentrations, as a potential fungicide application on Fusarium solani f. sp. phaseoli, in laboratory conditions.

\section{MATERIAL AND METHODS}

\section{Plant material}

The $P$. ramiflora leaves were collected from 13 matrices located in Cerrado areas, region of Taboco $\left(20^{\circ} 29^{\prime} 79^{\prime \prime} \mathrm{S} 55^{\circ} 48^{\prime} 7^{\prime} \mathrm{O}\right.$ and $19^{\circ} 26^{\prime} 10.10^{\prime \prime} \mathrm{S}$ $\left.55^{\circ} 00^{\prime} 2.78^{\prime \prime O}\right)$, municipality of Corguinho, Mato Grosso do Sul, in Brazil. The collection was manual, with the aid of pruning scissors and trimmer, with material wrapped in polyethylene bags and transported to the laboratory. After the identification, a copy was cataloged (7829) and incorporated into the herbarium collection.

From the collected botanical material, intact leaves were used, being excluded the old or damaged leaves. After drying at room temperature $\left( \pm 27^{\circ} \mathrm{C}\right)$ for three days on the lab bench lined with kraft paper, the material was triturated in electrical mill (MARCONI ${ }^{\circledR}$, MA048) and the powder stored in airtight amber glass, labeled and packaged at 10 ${ }^{\circ} \mathrm{C}$ until the extracts preparation.

\section{Obtaining the plant extract and partition}

The leaves powder (800 g) of the plant was subjected to extraction with ethanol, by ultrasonic bath (UNIDQUE $\left.{ }^{\circledR}, 1450\right)$ for 60 minutes, followed by 24 hours of static extraction by maceration for 30 days, at room temperature $\left(23\right.$ to $\left.28{ }^{\circ} \mathrm{C}\right)$; after filtration, the solvent was eliminated in a rotary evaporator, obtaining the extract $\mathrm{Ext}_{\mathrm{EtOH}}$ (crude ethanolic extract ) (27.8 g).

For the substances semi purification (CECHINEL FILHO; YUNES, 2001) present in the extract, part of the material (20 g) was suspended in methanol/water solution (80:20) and subjected to liquid-liquid partition, with organic solvents of different polarities: hexane, dichloromethane, chloroform, ethyl acetate and n-butanol; the residue was characterized as a hydroethanolic fraction.

The solvents were eliminated in rotary evaporators, obtaining the following yields (fraction): hexane $\left(\mathrm{F}_{\mathrm{Hex}}=5.8 \mathrm{~g}\right)$, dichloromethane $\left(\mathrm{F}_{\mathrm{CH} 2 \mathrm{Cl} 2}=3.1 \mathrm{~g}\right)$, chloroform $\left(\mathrm{F}_{\mathrm{CHCl} 3}=2.2 \mathrm{~g}\right)$, ethyl acetate $\left(\mathrm{F}_{\text {Acoet }}=0.98 \mathrm{~g}\right)$, n-butanol $\left(\mathrm{F}_{\mathrm{BuOH}}=2.4 \mathrm{~g}\right)$, and hydroethanolic $\left(\mathrm{F}_{\mathrm{H} 2 \mathrm{O} / \mathrm{MeOH}}=4.4 \mathrm{~g}\right)$.
The chemical profile of extract and fractions was determined by phytochemical screening and confirmation of the majority groups by UV-Visible spectrum $\left(\mathrm{FEMTO}^{\circledR}, 800 \mathrm{XI}\right)$ determined in the lengthwave range 200 to $800 \mathrm{~nm}$ in quartz cuvettes. The analyzes were carried out with three repetitions and the absorption bands, compared with the literature (SILVERSTEIN et al., 2014). The solvent used was methanol for liquid chromatography of high efficiency.

\section{Biological assay in vitro}

The fungus used in the antifungal assay was preserved in tubes containing PDA culture medium (potato-dextrose-agar), in refrigerator. Seven days before its use, it was transferred to Petri plates containing the PDA and placed in B.O.D. $\left( \pm 25^{\circ} \mathrm{C}\right)$.

For bioassays, a stock solution was prepared of the crude ethanolic extract and of each of the fractions $\left(\mathrm{F}_{\mathrm{Hex}} ; \mathrm{F}_{\mathrm{CH} 2 \mathrm{Cl} 2} \mathrm{~F}_{\mathrm{CHCl} 3} ; \mathrm{F}_{\mathrm{Acoet}} ; \mathrm{F}_{\mathrm{BuOH}}\right.$ and, $\mathrm{F}_{\mathrm{H} 2 \mathrm{O} / \mathrm{MeOH}}$ ), using $0.2 \mathrm{~g}$ of the samples and completed the volume with the respective solvents until the volume of $100 \mathrm{~mL}$, in volumetric flask. Of the $\mathrm{Ext}_{\text {ЕTOH }}$ stock solutions and fractions, a new dilution was performed to obtain the concentration of $500 \mu \mathrm{g}$ $\mathrm{m} / \mathrm{L}$, using as solvent a hydroethanolic solution to $20 \%$, with $5 \mu \mathrm{L}$ of dimethyl sulfoxide.

These solutions $(500 \mu \mathrm{g} \mathrm{m} / \mathrm{L})$ were used in bioassays and an aliquot of each one was incorporated into heated PDA medium $\left( \pm 45^{\circ} \mathrm{C}\right)$, at concentrations of $800,1200,1600,2000$ and 2400 $\mu \mathrm{g} / \mathrm{mL}$, besides the PDA, pure, as a control. Subsequently, $10 \mathrm{~mL}$ of the medium, with the different concentrations, were poured, individually, in sterile Petri dishes, and then in a $0.5 \mathrm{~cm}$ disc in diameter with spores and mycelium, separately, Fsp in the center of each plate.

Afterward, the plates were randomly distributed in B.O.D., incubated at $25 \pm 2{ }^{\circ} \mathrm{C}$. With a digital pachymeter, colonies were measured diametrically (average of two perpendicular measurements), until the controls mycelial growth reached the plates edges (about three days). Then, rate of mycelial growth speed was calculated: $I V C M=\frac{\Sigma(d-d a)}{N}$, where IVCM = speed of mycelial growth index; $\mathrm{D}=$ current average diameter of the colony; $\mathrm{da}=$ average diameter of the colony of the previous day; and, $\mathrm{N}=$ number of days after inoculation.

The experimental design was completely randomized with five replicates, the treatments being constituted of an extract and six fractions, beyond the control. Of the IVCM, the analysis of variance was carried out using PROC GLM 
procedure of SAS application and when significant, the regression analysis was performed using the PROC REG and NLIN procedures (SAS, 2001).

\section{RESULTS AND DISCUSSION}

The results for the extract phytochemical screening $\left(\mathrm{Ext}_{\mathrm{EtOH}}\right)$ (Figure 1) and its fractions
(Figure 2) show that the extract presents a greater diversity of phytochemicals (nine classes), with a predominance of phenolic compounds and derivatives (flavonoids and anthraquinones) and polar compounds, such as steroids and triterpenes and polars, as reducing sugars.

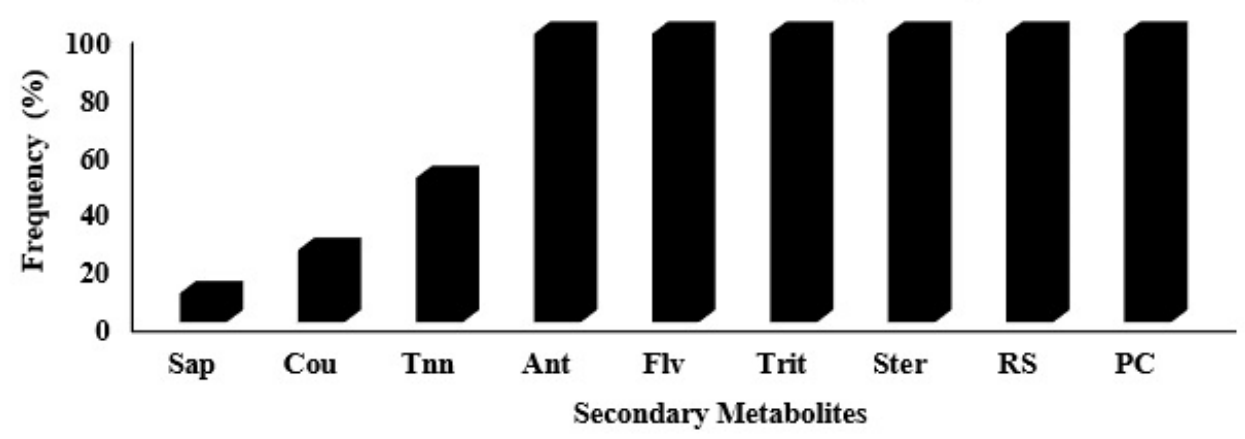

Figure 1. Chemical profile of the crude ethanolic extract of $P$. ramiflora leaves $(\mathrm{Sap}=$ saponins, Cou= coumarins, $T n n=$ tannins, Ant $=$ anthraquinones, Flv $=$ flavonoids, Trit $=$ triterpenes, Ster $=$ steroids, $\mathrm{RS}=$ reducing sugars, and, $\mathrm{PC}=$ phenolic compounds).

With the semi purification using solvents in increasing gradient polarity, it was observed the separation of the constituents by polarity. Of the fractions obtained in hydroethanolic fraction $\left(\mathrm{F}_{\mathrm{H} 2 \mathrm{O} / \mathrm{MeOH}}\right)$ (Figure 2), six classes of constituents were detected, with higher frequency for the reducing sugars that normally are not translocated in the phloem, which may occur in its accumulation (TAIZ; ZEIGER, 2013).

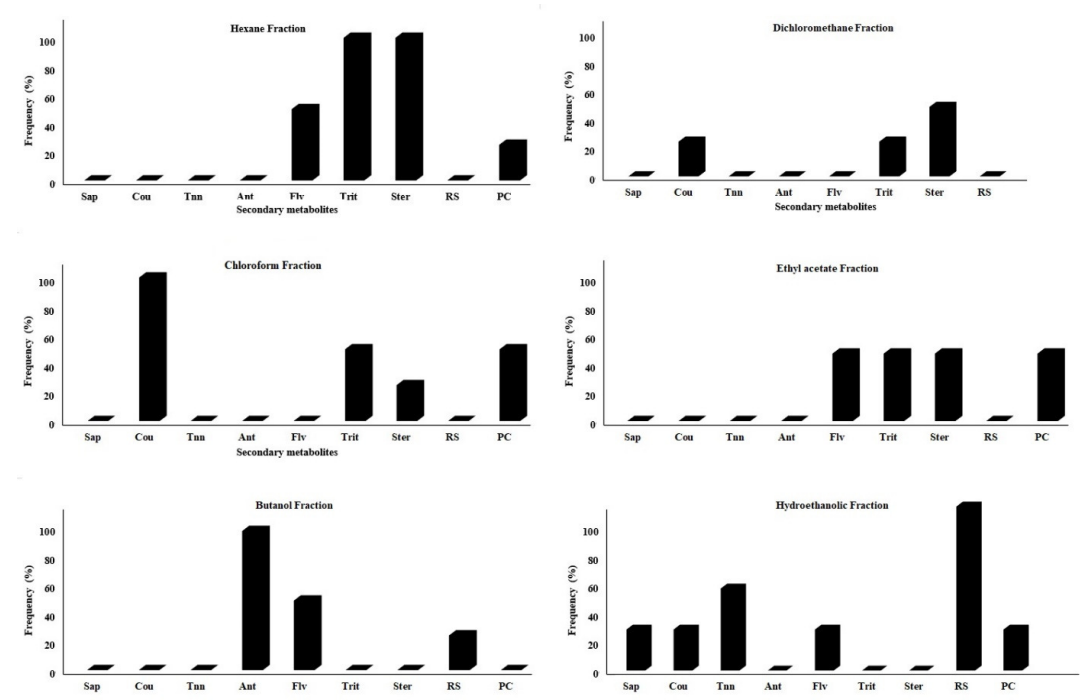

Figure 2. Chemical profile of the fractions (Hexane, Dichloromethane, Chloroform, Ethyl Acetate, Butanol and Hydroethanolic), $P$. ramiflora leaves $(\mathrm{Sap}=$ saponins, $\mathrm{Cou}=$ coumarins, $\mathrm{Tnn}=\mathrm{tannins,} \mathrm{Ant=}$ anthraquinones, Flv= flavonoids, Trit $=$ triterpenes, $\mathrm{Ster}=$ steroids, $\mathrm{RS}=$ reducing sugars, and, $\mathrm{PC}=$ phenolic compounds).

Thus, there is the presence of sugars characterized as unusual (amino-deoxy sugars, methylated sugars and, sugars with branched carbon chain), products of oxidation or reduction of other metabolites (KREIS et al., 2017). These sugars have high solubility in polar solvents as the hydroethanolic; with this same profile are the

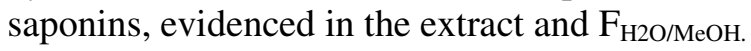


In the apolar fractions $\left(\mathrm{F}_{\mathrm{Hex}}\right.$ and $\left.\mathrm{F}_{\mathrm{CH} 2 \mathrm{Cl} 2}\right)$, the steroids stand out; in the medium polarity, as $\mathrm{F}_{\mathrm{CHCl} 3}$, coumarins and in $\mathrm{F}_{\text {Acoet }}$, phenolic compounds, flavonoids, steroids and triterpenes (Figure 2).

The spectrum of ethanolic extract scanning (Figure 3) and fractions (Figure 4) confirmed the chemical profile results (Figures 1 and 2). In general, the results obtained by scanning in the absorption spectrum in the UV-visible region showed that all the samples have similar maximum absorption bands between 330 and $390 \mathrm{~nm}$, corresponding to the phenolic compounds and

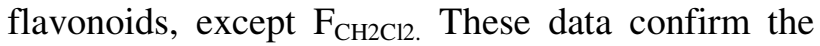
predominance of these two classes of secondary metabolites. The spectra show the same chemical profile reported by Oliveira et al. (2017), to the $P$. ramiflora leaves. The flavonoids exhibit in the visible ultraviolet two maximum peaks of absorption, one between 240-285 $\mathrm{nm}$ and another, 300-400 nm (ZUANAZZI; MONTANHA, 2003).

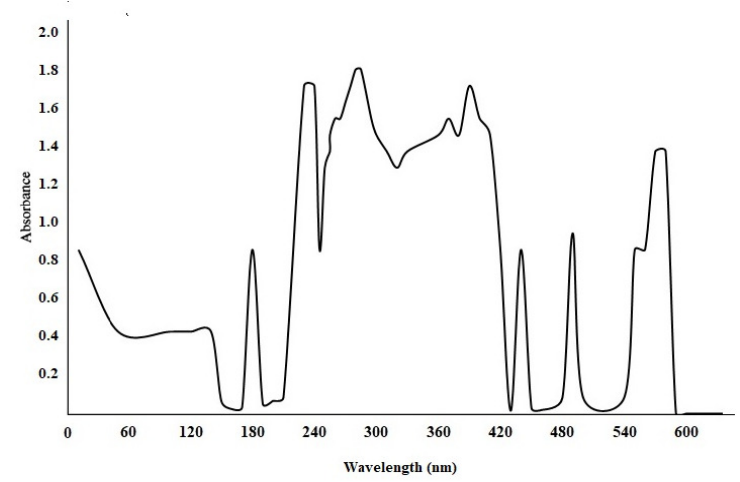

Figure 3. Absorption spectra in the UV-Visible region of the ethanolic extract of the Pouteria ramiflora leaves.

According to Silverstein et al. (2014), the absorption between 430 to $490 \mathrm{~nm}$ refers to anthraquinones, what is observed for $\operatorname{Ext}_{\mathrm{EtOH}}$ and $\mathrm{F}_{\mathrm{Hex}}, \mathrm{F}_{\mathrm{Acoet}}$ and $\mathrm{F}_{\mathrm{BuOH}}$. In the qualitative analysis, this chemical group was detected by Oliveira et al. (2017) only in $\mathrm{Ext}_{\mathrm{EtOH}}$ and $\mathrm{F}_{\mathrm{BuOH}}$. On the other hand, the steroids, because they are heterocyclic, have characteristic absorption between 275 to $356 \mathrm{~mm}$ (SILVERSTEIN et al., 2014), situation observed in the spectrum of the ethanolic extract and $\mathrm{F}_{\mathrm{Hex}}$, $\mathrm{F}_{\mathrm{CH} 2 \mathrm{Cl} 2}$ and $\mathrm{F}_{\text {Acoet }}$ (Figure 4).
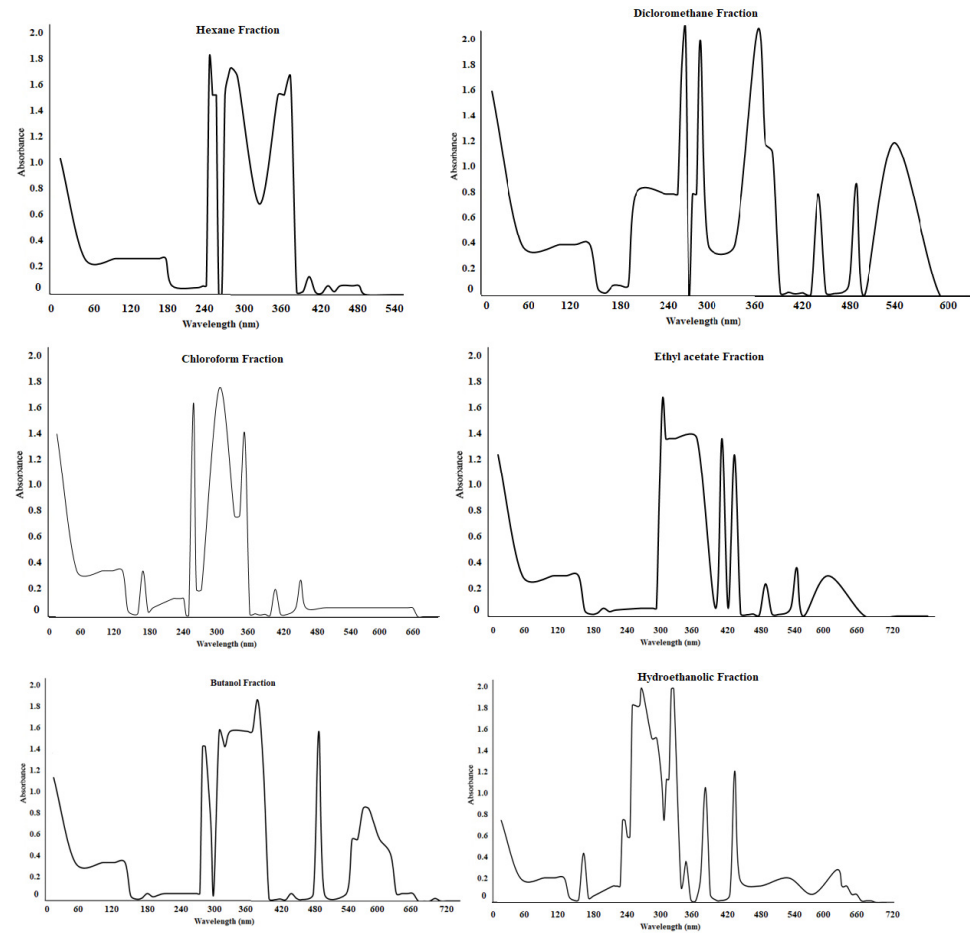

Figure 4. Absorption spectra in the UV-Visible region (hexane, dichloromethane, chloroform, ethyl acetate, butanol and hydro ethanol) of Pouteria ramiflora leaves. 
In the spectrum of UV-Visible it is possible to monitor the radiation absorption by molecules of chemical compounds and, by comparing the sample, correlate with absorption in pre-established wavelengths, i.e., tabulated; in this analysis it is worked in micro scale, being possible to detect chemical groups in lower concentrations (SILVERSTEIN et al., 2014).

The principal constituents mentioned for the species of the genus are the triterpenes (simple and long-chain or acetate esters) and flavonoids. The long-chain hydrocarbons, alcohols, acids and esters were also mentioned, especially in species that occur in dry regions, as for example, in savannah areas, in Brazil (SILVA et al., 2009).

Anthraquinones were not recorded for other species of the genus and only recently, for the $P$. ramiflora barks, also collected in the Cerrado region in Mato Grosso do Sul (OLIVEIRA et al., 2014). These authors evidenced, in the analyzed extract, in addition to the free anthraquinones, the presence of phenolic compounds, tannins, coumarins, sugars and saponins in inner and outer bark of the stem, aqueous extract and ethanol extracts and also steroids and triterpenes, only in the ethanolic.

The phenolic compounds were also described for $P$. campechiana Kunth and tannins, for fruits of $P$. gardneriana (ROCHA et al., 2011), for exemple. Carriço et al. (2014), upon investigating the aqueous extract of the Pouteria sapota (Jacq.) leaves H. E. Moore \& Stearn, found flavonoids, coumarins, glycosides cyanogenic and reducing sugars, as the classes of more abundant secondary metabolites, demonstrating the diversity of substances present in species of the genus Pouteria.

\section{Antifungal activity of ethanolic extract and fractions}

The results presented by different fractions and the extract showed a distinct behavior, affecting the IVCM in greater or lesser degree, depending on the solvent used. The fraction that presented the lowest effect was $\mathrm{F}_{\text {Acoet }}$ (Figure 5), with a reduction in the IVCM being more effective for $800 \mu \mathrm{g} / \mathrm{mL}$ $(11.26 \mathrm{~mm} /$ day $)$; the IVCM remained with values close to those obtained initially as the concentrations increased.

This result is probably associated with the used solvent, ethyl acetate, which solubilized some metabolites present on the leaves (Figure 2), with medium intensity of $50 \%$ (phenolic compounds, flavonoids, triterpenes and steroids), resulting in the end, in a reduction of $28.8 \%$ of IVCM, in relation to the control group.

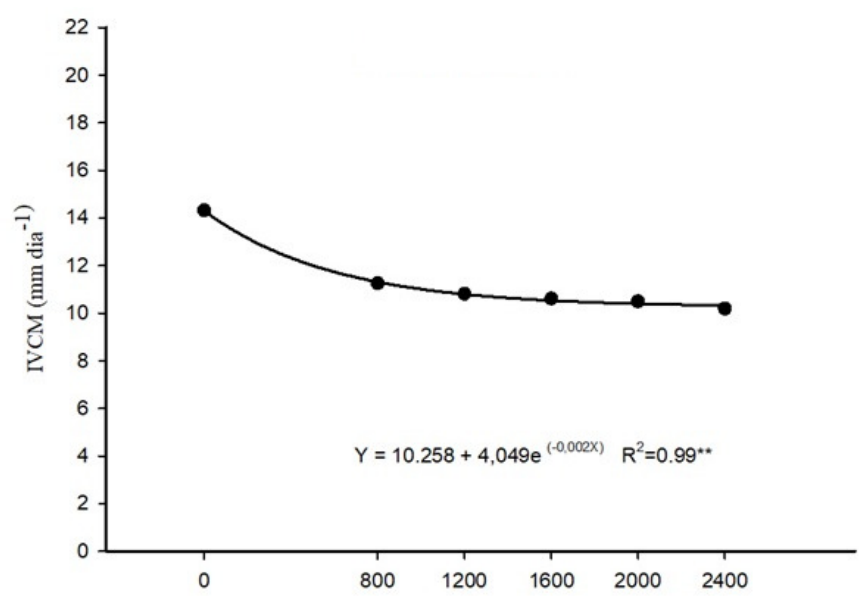

Figure 5. Mycelial growth speed index in vitro of Fusarium solani f. sp. phaseoli subjected to different concentrations of ethyl acetate fraction of Pouteria ramiflora leaves.

The $\mathrm{F}_{\mathrm{H} 2 \mathrm{O} / \mathrm{MeOH}}$ presented similar behavior (Figure 6), with reduced antifungal activity to a concentration of $800 \mu \mathrm{g} / \mathrm{mL}\left(16.80 \mathrm{~mm} \mathrm{day}^{-1}\right)$ and later, keeping values significantly stable until 1600 $\mu \mathrm{g} / \mathrm{mL}(18.08 \mathrm{~mm} /$ day $)$; however, when observed the values of IVCM to $2400 \mu \mathrm{g} / \mathrm{mL}$, it was noted the value of $11.80 \mathrm{~mm} / \mathrm{day}$, similar to that found for $\mathrm{F}_{\text {Acoet. }}$.

This fraction presents as components, reducing sugars in high intensity, tannins on average, and phenolic compounds, flavonoids, coumarins, and saponins in low intensity (Figure 2). Thus, the solvent hydroethanolic was able to extract a larger number of metabolites; however, despite the greater diversity, probably the intensity of these compounds was not sufficient to produce a significant reduction in higher concentrations. Only when it was used $2400 \mu \mathrm{g} / \mathrm{mL}$, the IVCM reached $39.5 \%$. 


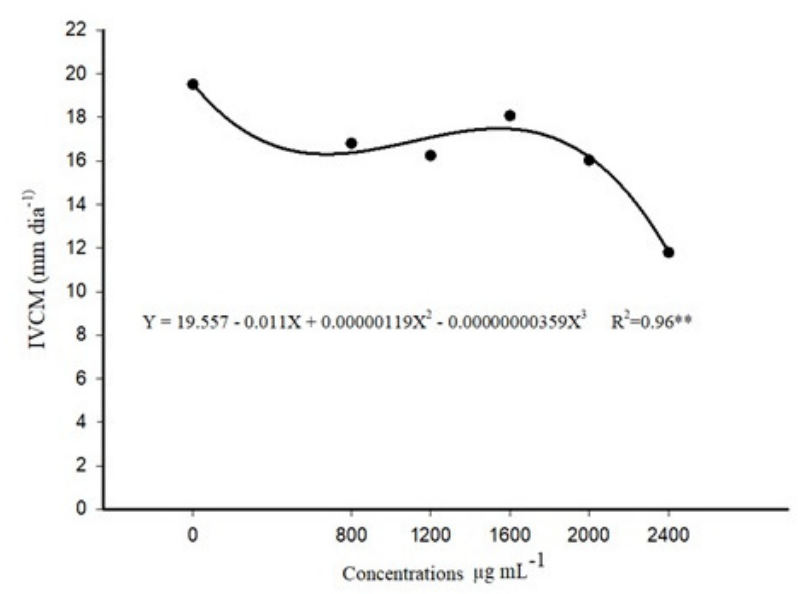

Figure 6. Mycelial growth speed index in vitro of Fusarium solani f. sp. phaseoli subjected to different concentrations of hydroethanolic fraction of Pouteria ramiflora leaves.

Similar results were found by Oliveira et al. (2017), where the IVCM of $L$. theobromae was reduced by up to $33 \%$ through the use of ethyl acetate and hydroethanolic fraction obtained from $P$. ramiflora leaves, demonstrating that these fractions have a small action in the fungi growth. However, these in vitro tests are essential for the selection of possible agents of alternative diseases control, as well as observed by Faria et al. (2009), upon working with application of hydroethanolic extract of Momordica charantia L. before planting, in a preventive manner, observed a reduction of $74 \%$ of the disease severity caused by the fungus Sclerotium rolfsii. These results indicate that there is potential to use this type of fraction.

On the other hand, the ethanolic extract and the fractions, chloroform and dichloromethane (Figure 7) demonstrated a trend of gradual decrease in IVCM from the concentration of $800 \mu \mathrm{g} / \mathrm{mL}$, with lower values observed at the highest concentration $(2400 \mu \mathrm{g} / \mathrm{mL})$, the latter being $8.75 \mathrm{~mm} /$ day $\mathrm{F}_{\mathrm{CH} 2 \mathrm{Cl} 2}, 8.49 \mathrm{~mm} /$ day $-\mathrm{F}_{\mathrm{CHCl} 3}, 2.75 \mathrm{~mm} /$ day $-\mathrm{F}_{\mathrm{Hex}}$ and $8.59 \mathrm{~mm} /$ day for Ext $_{\mathrm{EtOH}}$.

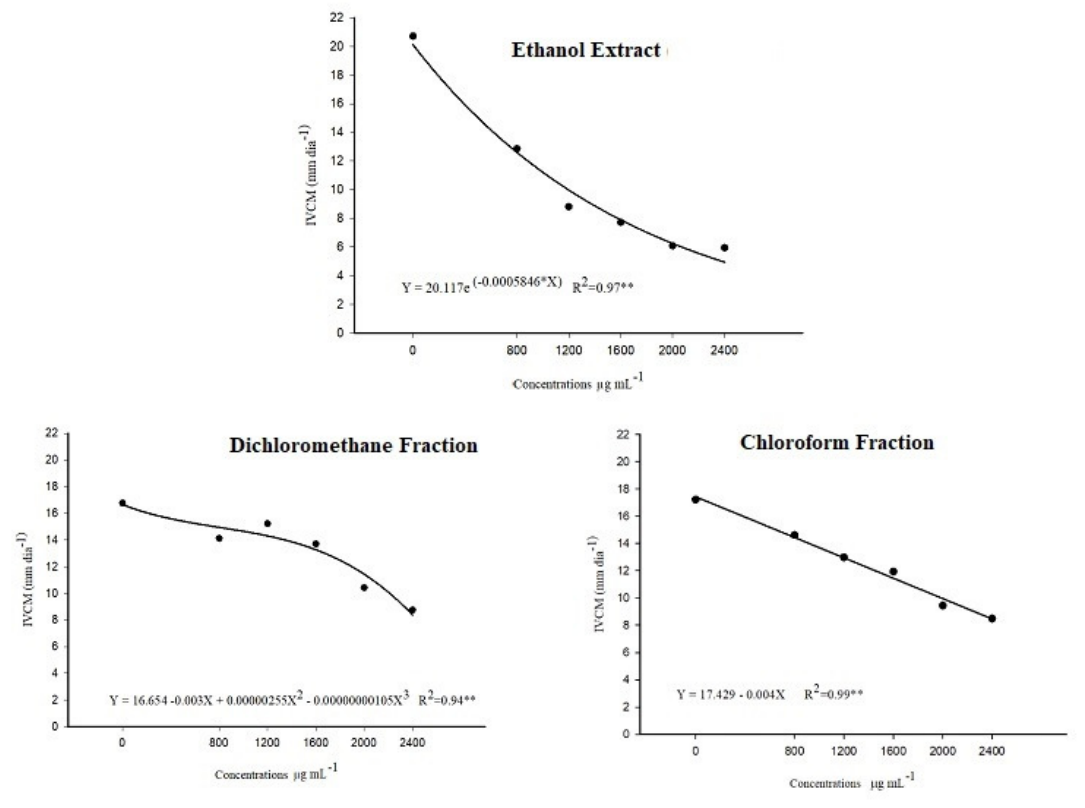

Figure 7. Mycelial growth speed index in vitro of Fusarium solani subjected to different concentrations of dichloromethane, chloroform and ethanolic extract of Pouteria ramiflora leaves.

The metabolic disorders found in $\mathrm{F}_{\mathrm{CH} 2 \mathrm{Cl} 2}$ were phenolic compounds, partial intensity, coumarins, low, and steroids, medium intensity; $\mathrm{F}_{\mathrm{Hex}}$, phenolic compounds, low intensity, flavonoids, medium, and triterpenes and steroids, high intensity
(Figure 2), and $\mathrm{Ext}_{\mathrm{EtOH}}$, coumarins, low intensity, tannins, medium, and phenolic compounds, flavonoids, anthraquinones, triterpenes, steroids and sugars, high intensity, being that the ethanolic 
extract showed the highest number of constituents, in higher intensities (Figure 1).

The differences in the metabolites found and their intensity, according to Tijani et al. (2009), are the result of using different types of solvents, which influence the secondary metabolites class. The diversity of these compounds resulted, in the end, in significant reductions in the IVCM, reaching $47.8 \%$ (dichloromethane), $50.7 \%$ (chloroform) and $71.3 \%$ $\left(\mathrm{Ext}_{\mathrm{EtOH}}\right)$, comparing to the control. Oliveira et al. (2017) found similar results, also using $P$. ramiflora leaves and testing their action against $L$. theobromae, mentioning reduction in IVCM of $52.9 \%$ to dichloromethane and $59.6 \%$ for extract. However, the use of chloroform fraction resulted in a reduction in IVCM of $20.2 \%$, much lower that the found by this research. The differences are probably related to the characteristics among the evaluated fungi, which have distinct physiology, responding differently to the different tested metabolites.

Other studies related, with the use of dichloromethane, have already proved to be effective, as reported by Camatti-Sartori et al. (2011), in tests with ethanol extracts of Matricaria chamomilla L. that indicated that inhibition of 50 and $40 \%$ in the phytopathogen Fusarium sp. growth in concentrations of 25 and $50 \%$, respectively. Lima and Ferreira Neto (2014) found similar results, demonstrating the potential fungicide on Rhizoctonia solani when used the ethanolic extract of Solanum grandiflorum fruits Ruiz \& Pav. and indicating their potential for use in combating the pathogen inhabitants of soil, similar to that demonstrated by this research.

The fractions with greater efficiency in controlling the fungus growth were $\mathrm{F}_{\mathrm{Hex}}$ and $\mathrm{F}_{\mathrm{BuOH}}$ (Figure 8). The metabolites composition of both is distinct, presenting $\mathrm{F}_{\mathrm{Hex}}$ phenolic compounds, low intensity, flavonoids, medium, and triterpenes and steroids, high intensity. $\mathrm{F}_{\mathrm{BuOH}}$, reducing sugars, low intensity, flavonoids, medium and, anthraquinones, high intensity (Figure 2).
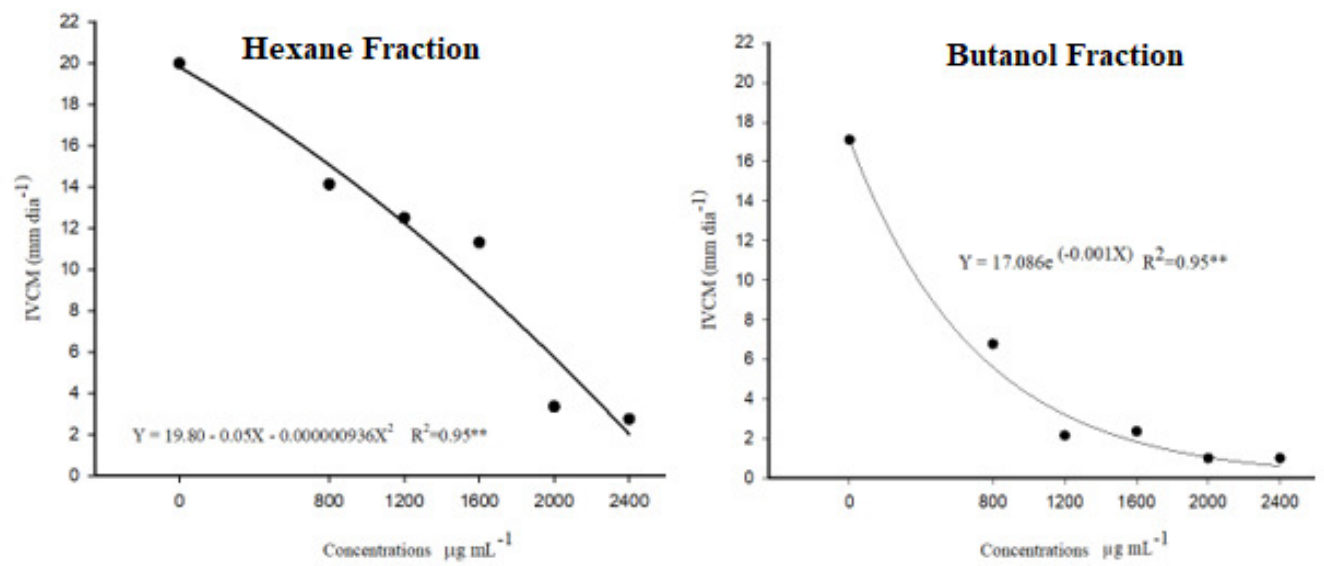

Figure 8. Mycelial growth speed index of Fusarium solani in vitro subjected to different concentrations of hexane and butanol of Pouteria ramiflora leaves.

Both fractions showed an increased action of inhibition, to the extent that the concentrations increased. At the end of the third day, $\mathrm{F}_{\mathrm{Hex}}$ resulted in $86.2 \%$ reduction of IVCM $(2400 \mu \mathrm{g} / \mathrm{mL})$, while $\mathrm{F}_{\mathrm{BuOH}}$ inhibited $94.1 \%(2000 \mu \mathrm{g} / \mathrm{mL})$, in relation to the control. Thus, it can be assumed that the solvent of this fraction, butanol, provided a better extraction of compounds, resulting in a lower growth index of $F$. solani. Probably this factor is related to the strong presence of anthraquinones, considered metabolites that have antimicrobial activity, among others (MISHRA et al., 2010)

On the other hand, $\mathrm{F}_{\mathrm{Hex}}$ has no anthraquinones, but a set of metabolites are also found in other extracts, likely resulting in processes of synergy, where the combination on the performance of two or more compounds leads to greater efficiency, maximized when they act together.

Hexanic extracts also revealed greater antifungal activity in studies performed by Domingues et al. (2009) than ethanol, obtained from Ruta graveolens L., Allamanda catartica L. and Impatiens walleriana Hook. f. on the fungus Sclerotium rolfsii, whereas I. walleriana was more effective for Alternaria solani, both soils inhabitants fungi. According to the same authors, the substances derived from plants are better extracted by hexane (apolar solvent) than by the ethanol (solvent polar).

Regarding the butanol and iso-butanol based solvents, studies with stored grains of sorghum demonstrated their efficacy as inhibitors of common 
pathogens in storage conditions, such as Aspergillus and Penicillium (PINTO, 2004).

In the fraction with butanol, the major constituents were the anthraquinones (Figures 2 and 4), absorption band at $490 \mathrm{~nm}$ (SILVERSTEIN et al., 2014). The naphthoquinones are widely studied by owning several biological activities, among them their antifungal effect (SHENG; ZHANG, 2011). In general, the naphthoquinones act directly and/or indirectly in cell envelope (wall and/or plasma membrane) and, particularly, in the biosynthesis of ergosterol, which is the main component of the fungi cell membrane (KATHIRAVAN et al., 2012). The differences in results, using the same solvents, is related to species of plant used, because each plant can present different compositions of allelochemicals and hence, interfere differently on the phytopathogens.

Oliveira et al. (2017) also showed that the fraction $\mathrm{F}_{\mathrm{BuOH}}$ was more effective against $L$. theobromae, with a reduction of $94.2 \%$ in the IVCM; however, $\mathrm{F}_{\mathrm{Hex}}$ presented only $49.5 \%$. Again the differences of results are probably related to the distinct characteristics among the evaluated fungi, which due to being different species, have distinct physiology, responding differently to different metabolites.

The trend observed, for most of the solvents, is their action have greater fungitoxic effect as the concentration increases, also reported by Motoyama et al. (2003), who reported that the higher the extract concentration, the greater the mycelial growth inhibition. This same trend was also observed by Venturoso et al. (2011), in assays with Syzygium aromaticum (L.) Merr. \& L.M.Perry. and Cinnamomum zeylanicum Blume on the growth of the fungus $F$. solani.

These results are normally related to the increase of metabolites found, because this means that the allelochemicals present will be found in greater intensity. However, there is a general rule, because in some situations, when increasing the concentrations, the respective increase of inhibition does not occur, due to changes in the balance of the substances present in the extracts. This situation is reported by Souza et al. (2007), with Fusarium proliferatum and extract of Allium sativum L., indicating that the concentrations of 10 and $5 \%$ propitiated smaller colony diameters, comparing to the largest, demonstrating that, in certain situations, a lower concentration can also be effective.

The data obtained demonstrate the viability of the use of plant extracts for the control of certain fungi, which had already been observed by Silva et al. (2009), working with $P$. ramiflora, upon using pyroligneous extract and indicate fungitoxic activity for Aspergillus niger and Trichoderma sp. and Oliveira et al. (2017), using the same species and evaluating its fungitoxic effect against $L$. theobromae. However, further studies are necessary to determine, specifically, what the metabolites are that have greater action, since the results presented indicate that different fractions inhibited, in greater or lesser degree, the IVCM.

\section{CONCLUSION}

The fractions that inhibited with greater effectiveness the Fsp development, with a lower mycelial growth index, were hexane and butanol, at concentrations of 2400 and $2000 \mu \mathrm{g} / \mathrm{mL}$, in which the presence of different metabolites was effective to affect the mycelial growth rate.

\section{ACKNOWLEDGMENTS}

To CAPES for scholarships for master and doctoral degrees and also to $\mathrm{CNPq}$, to Productivity Scholarships in Research (PQ2) and Scientific Initiation (PIBIC), granted. And the financial support from CNPq, CPP, INAU, FUNDECT and the University Anhanguera-Uniderp for funding of Interdisciplinary Research Group (GIP) and Natural Products (PN).

RESUMO: Entre os fungos que acometem a cultura do feijão está Fusarium solani f.sp. phaseoli, causando perdas na produtividade. Levando-se em consideração sua importância, o objetivo deste trabalho foi determinar a classe de metabólitos secundários e o potencial fungicida das folhas de curriola (Pouteria ramiflora) sobre $F$. solani, em condições de laboratório. O extrato etanólico foi dissolvido em metanol/água e particionado sucessivamente com hexâno, diclorometano, clorofórmio, acetato de etila e butanol, submetidos ao perfil químico. As soluções foram preparadas nas concentrações de 800,1200, 1600, 2000 e $2400 \mu \mathrm{g} / \mathrm{mL}$ e vertidas em placas de petri $(10 \mathrm{~mL})$; em seguida, foi depositado um disco de $0,5 \mathrm{~cm}$ de diâmetro com esporos e micélio de $F$. solani. As placas foram incubadas a temperatura de $25 \pm 2{ }^{\circ} \mathrm{C}$ e as avaliações, realizadas por meio da medição do diâmetro das colônias (cinco repetições) até atingir a borda da placa (três dias), com delineamento experimental inteiramente casualizado. Através dos dados do Índice de Velocidade de Crescimento Micelial (IVCM), foi realizada a análise de variância e quando significativa, aplicada a análise de 
regressão. Os resultados indicaram que todos as frações e o extrato possuem os compostos fenólicos e/ou derivados como um dos constituintes majoritários, exceto a fração hidrometanólica. $\mathrm{O}$ extrato e suas frações diminuíram o IVCM de $F$. solani, à medida que se aumentava as concentrações; a maior redução ocorreu na fração butanolica para a concentração de $2400 \mu \mathrm{g} / \mathrm{mL}$, com crescimento próximo a zero, indicando seu potencial de uso para controle de $F$. solani, provavelmente devido a presença de antraquinonas em sua composição. Antraquinonas.

PALAVRAS-ChaVE: Feijão comum. Fungos patogênicos. Fungos de solo. Flavonoides.

\section{REFERENCES}

CAMATTI-SARTORI, V.; MAGRINI, F. E.; CRIPPA, L. B.; MARCHETT, C.; VENTURIN, L.; SILVARIBEIRO, R. T. Avaliação in vitro de extratos vegetais para o controle de fungos patogênicos de flores. Revista Brasileira de Agroecologia, Cruz Alta, v. 6, n. 2, p. 117-122, 2011.

CARRIÇO, C.; PINTO, Z. T.; DUTOK, C. M. S.; CAETANO, R. L.; PESSANHA, R. R.; CHIL-NUÑEZ, I.; MENDONÇA, P. M.; ESCALONA-ARRANZ, J. C.; REYES-TUR, B.; QUEIROZ, M. M. C. Biological activity of Pouteria sapota leaf extract on post-embryonic development of blowfly Chrysomya putoria (Wiedemann, 1818) (Calliphoridae). Revista Brasileira de Farmacognosia, Curitiba, v. 24, n. 3, p. 304-308, 2014. https://doi.org/10.1016/j.bjp.2014.07.007

CASA, R. T.; KRIEGER, I.; KUHNEM JUNIOR, P. R.; BOGO, A.; MOREIRA, E. N.; RIZZI, F. P. Podridão radicular em feijão no sistema plantio direto. Revista de Ciências Agroveterinárias, Lages, v. 10, n. 1, p. 37 43, 2011.

CECHINEL FILHO, V.; YUNES, R. A. Estudo químico de plantas medicinais orientado para análise biológica. Obtenção, determinação e modificação estrutural de compostos bioativo. In: YUNES, R. A.; CALIXTO, J. B. (Eds.). Plantas medicinais sob a ótica da química medicinal moderna. Chapecó: Argos, 2001. p. 47-75.

DI PIERO, R. M.; NOVAES, Q. S.; PASCHOLATI, S. F. Effect of Agaricus brasiliensis and Lentinula edodes mushrooms on the infection of passionflower with cowpea aphid-borne mosaic virus. Brazilian Archives of Biology and Technology, Curitiba, v. 53, n. 2, p. 269-278, 2010. https://doi.org/10.1590/S151689132010000200004

DOMINGUES, R. J.; SOUZA, J. D. F.; TÖFOLI, J. G.; MATHEUS, D. R. Ação “in vitro" de extratos vegetais sobre Colletotrichum acutatum, Alternaria solani e Sclerotium rolfsii. Arquivos do Instituto Biológico, São Paulo, v. 76, n. 4, p. 643-649, 2009.

FARIA, F. A.; BUENO, C. J.; PAPA, M. F. S. Atividade fungitóxica de Momordica charantia L. no controle de Sclerotium rolfsii Sacc. Acta Scientiarum. Agronomy, Maringá, v. 31, p. 383-389, 2009.

GARCIA, R. A.; MIRANDA, B. A.; LOBO JÚNIOR, M.; ARAÚJO, F. G.; CUNHA, M. G. Efeito de compostos orgânicos sobre podridões radiculares no feijoeiro comum. Bioscience Journal, Uberlândia, v. 30, n. 1, p. 25-32, 2014.

KATHIRAVAN, M. K.; SALAKE, A. B.; CHOTHE, A. S.; DUDHE, P. B.; WATODE, R. P.; MUKTA, M. S.; MURATA, M. The biology and chemistry of antifungal agents: A review. Bioorganic \& Medicinal Chemistry, Bethesda, v. 20, n. 19, p. 5669-5677, 2012. https://doi.org/10.1016/j.bmc.2012.04.045 KREIS, W.; MUNKERT, J.; PÁDUA, R. M. Biossintese de metabólitos primários e secundários. In: SIMÕES, C. M. O.; SCHENKEL, E. P.; MELLO, J. C. P.; MENTZ, L. A.; PETROVICK, P. R. Farmacognosia: do produto natural ao medicamento. Porto Alegre: Artmed, 2017. p. 153-154. 
LESLIE, J. F.; SUMMERELL, B. A. The Fusarium Laboratory Manual. Oxford: Blackwell Publishing, 2006. 388 p. https://doi.org/10.1002/9780470278376

LIMA, R. A.; FERREIRA NETO, M. Atividade antifúngica do extrato etanólico dos frutos de Solanum grandiflorum sobre Rhizoctonia solani in vitro. Revista Saúde e Pesquisa, Maringá, v. 7, n. 1, p. 103-108, 2014.

MISHRA, B. B.; KISHORE, N.; TIWARI, V. K.; SINGH, D. D.; TRIPATHI, V.; HIDALGO, J. A.; VAZQUEZ, J. A. A novel antifungal anthraquinone from seeds of Aegle marmelos Correa (family Rutaceae). Fitoterapia, v. 81, n. 2, p. 104-107, 2010. https://doi.org/10.1016/j.fitote.2009.08.009

MOTOYAMA, M. M.; SCHWAN-ESTRADA, K. R. F.; STANGARLIN, J. R.; FIORI-TUTIDA, A. C. G.; SCAPIM, C. A. Indução de fitoalexinas em soja e em sorgo e efeito fungitóxico de extratos cítricos sobre Colletotrichum lagenarium e Fusarium semitectum. Acta Scientiarum. Agronomy, Maringá, v. 25, n. 2, p. 491-496, 2003.

OLIVEIRA, A. K. M.; PEREIRA, K. C. L.; MULLER, J. A. I.; MATIAS, R. Análise fitoquímica e potencial alelopático das cascas de Pouteria ramiflora na germinação de alface. Horticultura Brasileira, Vitória da Conquista, v. 32, n. 1, p. 41-47, 2014. https://doi.org/10.1590/S0102-05362014000100007

OLIVEIRA, A. K. M.; RIZZI, E. S.; PEREIRA, K. C. L.; BONO, J. A. M.; PINA, J. C.; MATIAS, R. Phytochemical analysis and fungicide potential of Pouteria ramiflora against Lasiodiplodia theobromae.

Horticultura Brasileira, Brasília, v. 35, n. 4, p., 2017.

PINTO, N. F. J. A. Patologia de grãos de sorgo. Sete Lagoas: Embrapa Milho e Sorgo, 2004. 10 p. (Embrapa Milho e Sorgo. Circular Técnica, 40).

REIS, E. M.; BEZERRA, R.; SCHEER, O.; MORAES, N. L. M.; CARDOSO, C. A. Manejo das podridões radiculares. In: REIS, E. M. Doenças na cultura da Soja. Passo Fundo: Aldeia Norte Editora, 2004. p. 115122.

ROCHA, W. S.; LOPES, R. M.; SILVA, D. B.; VIEIRA, R. F.; SILVA, J. P.; AGOSTINI-COSTA, T. D. S. Compostos fenólicos totais e taninos condensados em frutas nativas do cerrado. Revista Brasileira de Fruticultura, Jaboticabal, v. 33, n. 4, p.1215-1221, 2011.

SAS Institute. SAS user's guide: statistics, version 8.2. 6ed. Cary: Todd and Browde, 2001.

SHENG, C.; ZHANG, W. New lead structures in antifungal drug discovery. Current Medicinal Chemistry, Bethesda, v. 18, p.733-766, 2011. https://doi.org/10.2174/092986711794480113

SILVA, C. A. M.; SIMEONI, L. A.; SILVEIRA, D. Genus Pouteria: chemistry and biological activity. Revista Brasileira Farmacognosia, São Paulo, v. 19, n. 2, p. 501-509, 2009. https://doi.org/10.1590/S0102695X2009000300025

SILVERSTEIN, R. M.; WEBSTER, F. X.; KIEMLE, D. J.; DAVID L. B. Spectrometric identification of organic compounds $8^{\text {th }}$ edition. New Jersey: Jonh Wiley \& Sons, Inc. 2014. 464 p.

SOUZA, A. E. F.; ARAÚJO, E.; NASCIMENTO, L. C. Atividade antifúngica de extratos de alho e capimsanto sobre o desenvolvimento de Fusarium proliferatum isolado de grãos de milho. Fitopatologia Brasileira, Areia, v. 32, n. 6, p. 465-471, 2007. https://doi.org/10.1590/S0100-41582007000600003

TAIZ, L.; ZEIGER, E. Fisiologia Vegetal. 5ed. Porto Alegre: Artmed, 2013. 918 p.

TIJANI, A. Y.; OKHALE, S. E.; SALAWU, T. A.; ONIGBANJO, H. O.; OBIANODO, L. A.; AKINGBASOTE, J. A.; SALAWU, O. A.; OKOGUN, J. I.; KUNLE, F. O.; EMEJE, M. Antidiarrhoeal and 
antibacterial properties of crude aqueous stem bark extract and fractions of Parkia biglobosa (Jacq.) R. Br. Ex G. Don. African Journal of Pharmacy and Pharmacology, Lagos, v. 3, n. 7, p. 347-353, 2009.

VENTUROSO, L. R.; BACCHI, L. M. A.; GAVASSONI, W. L.; CONUS, L. A.; PONTIM, B. C. A.; SOUZA, F. R. Inibição do crescimento in vitro de fitopatógenos sob diferentes concentrações de extratos de plantas medicinais. Arquivos do Instituto Biológico, São Paulo, v. 78, p. 89-95, 2011.

ZUANAZZI, J. A.; MONTANHA, J. A. Flavonóides. In: SIMÕES, C. M. O.; SCHENKEL, E. P.; GOSMANN, G.; MELLO, J. C. P.; MENTZ, L. A.; PETROVICK, P. R. (Eds.). Farmacognosia: da planta ao medicamento. Florianópolis/Porto Alegre: UFSC/UFRGS, 2003. p. 577-614. 